\title{
A Simple Descriptive Study of Osteoarthritis among Libyan Patients who were Examined at the Jordanian Field Hospital in Benghazi City/ Libya
}

\author{
Kareem Al Rashdan*, Zaid Al Dahamsheh, Mohammad AlBakheet, Khaled Bani Hani and Emad Al Soub \\ Royal Medical Services, Jordan
}

Received: 制: November 05, 2018; Published: 制: November 13, 2018

*Corresponding author: Kareem Al Rashdan, Royal Medical Services, Jordan

\begin{abstract}
Introduction: Osteoarthritis $(\mathrm{OA})$ is the most common chronic arthritis impacts health parameters and quality of life. It affects old age, but it can occur in adults of any age.

Objectives: To study and describe OA cases among Libyan patients examined and treated in Jordanian field hospital in Benghazi City.

Study Design: A retrospective study was conducted to study the frequency and to describe the clinical patterns of OA cases among Libyan patients examined and treated in Jordanian field hospital in Benghazi City.

Methods and Subjects: A total of 1267 patients who visited the Jordanian field hospital in Benghazi and diagnosed to have OA between January 2012 and November 2012 were involved in this study. The patient's files were retrospectively reviewed and analyzed by the researchers at Royal medical services regarding gender, age, involved knee, BMI, social status and chronic diseases.

Statistical Analysis: The data was analyzed using SPSS version 21. Data was presented as means and standard deviation for continuous variable, and as frequencies and percentages for categorized variables. The relationships between study variables were examined based on Chisquare, and /or T test. Significance was considered at $\mathrm{P}$ value $<0.05$.

Result: The mean age was $59.31 \pm 8.2(35-80)$. The male to female ratio was $1: 3$. The mean BMI was $28.3 \pm 4.3$. The right knee was more involved than the left knee, $75.3 \%$ and $24.7 \%$ respectively. A significant positive correlation was found between BMI and pain severity $(0.351, \mathrm{p}<.05)$. Also, significant positive correlation was found between age and radiographic severity $(0.470, \mathrm{p}<0.01)$. The Females showed a higher incidence than males. A $65 \%$ of patients with chronic diseases had severe OA changes.

Conclusion: Our study showed that OA is highly prevalent among the Libyan population, and the risk factors (age, obesity, injury, sedentary work) are well identified. This can help to address a useful prevention program of the modifiable risk factors.
\end{abstract}

\section{Introduction}

Osteoarthritis $(\mathrm{OA})$ is a disease that has various characteristics such as chronic nature, various etiologies, developmentally degenerative of joint in association with sclerosis of subchondral bone, that is possible to end with bone cysts and marginal osteophytes [1,2]. Associated signs of OA include partial loss of knee flexibility, pain, lack of function and deformities [3]. From epidemiological point of view, osteoarthritis affects about $10 \%$ of males and $18 \%$ of females over 60 years [4,5]. The cost of treating of osteoarthritis is high and estimated to be in the range of $1.0 \%$ and $2 \cdot 5 \%$ of gross domestic product in developing countries [6]. The prevalence of osteoarthritis has been reported to increase with age and with gender females [7]. Although no exact etiology has been responsible for osteoarthritis, several risk factors have been associated with it such as the occurrence of microtraumas, knee surgery, metabolic factors, inheritance, obesity and joint overload [8-10].

The occurrence of osteoarthritis is initiated through the activation of innate immune system [5]. It has been found that chondrocytes express toll-like receptors that are activated by molecular products of tissue damage [11]. Osteoarthritis involves the existence of extracellular substances in the matrix such as the glycosaminoglycan hyaluronan [12]. Other players in the etiology 
of osteoarthritis include the binding of calcium pyrophosphate and sodium urate crystals to chondrocyte toll-like receptors [13]. Another immune mechanism involved in the etiology of osteoarthritis included the activation of complement system species [14].

\section{Study Objectives}

To study and describe OA cases among Libyan patients examined and treated in Jordanian field hospital in Benghazi City.

\section{Methods and Subjects}

A retrospective study was conducted. A total of 1267 patients who visited the Jordanian field hospital in Benghazi and diagnosed to have OA between January 2012 and November 2012 were involved in this study. The patient's files were retrospectively reviewed and analyzed by the researchers at Royal medical services regarding gender, age, involved knee, BMI, social status and chronic diseases. All data were entered to excel sheet for all patients prior to their analysis.

\section{Statistical Analysis}

The data was analyzed using SPSS version 21. Data was presented as means and standard deviation for continuous variable, and as frequencies and percentages for categorized variables. The relationships between study variables were examined based on $\mathrm{T}$ test. Significance was considered at $\mathrm{P}$ value $<0.05$.

\section{Results}

As shown in (Table 1), the mean age of patients was 59.3159.31 8.2 years. One quarter of study sample was males. BMI was $28.3 \pm$ 4.3 .

Table 1: General characteristics of participants.

\begin{tabular}{|c|c|}
\hline Variable & Description \\
\hline Age $(\mathrm{M} \pm \mathrm{SD}$ ) years & $59.31 \pm 8.2$ \\
\hline \multicolumn{2}{|c|}{ Gender (N, \%) } \\
\hline Males & $317(25 \%)$ \\
\hline Females & $950(75 \%)$ \\
\hline Body mass index (BMI) $(\mathrm{M} \pm \mathrm{SD})$ & $28.3 \pm 4.3$ \\
\hline
\end{tabular}

\section{Percentage of OA according to Knee Involvement}

As seen in (Figure 1), the majority of OA influenced right knee (about 75\%), and one quarter of cases was observed in left knee.

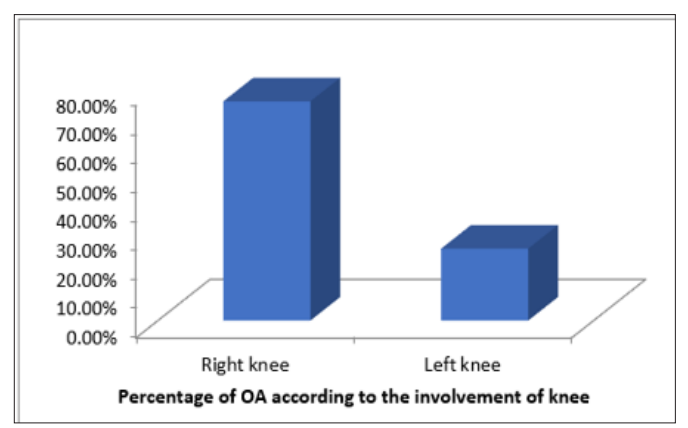

Figure 1: percentage of OA according to the knee involved.
The Correlation between Study Variables: As demonstrated in (Table 2), data showed a positive and significant correlation between BMI and pain severity $(0.35, \mathrm{p}<0.05)$, as well as between age and radiographic features $(0.47, \mathrm{p}<0.01)$.

Table 2: The correlation between study variables.

\begin{tabular}{|c|c|c|}
\hline Variables & Pearson & Significance \\
\hline BMI-pain severity & 0.35 & $<0.05$ \\
\hline Age - radiographic severity & 0.47 & $<0.01$ \\
\hline
\end{tabular}

\section{Discussion}

The data of the present study showed that Libyan patients with $\mathrm{OA}$ are like other populations worldwide regarding variables associated with OA. The mean age of patients in this study was about 60 years, the age in average for being diagnosed with OA. However, these findings are in line with previous studies including Woolf and Pfleger, and Glyn-Jones. Ageing may be predisposing factors for developing $\mathrm{OA}$ attributed to accumulative effects of inflammatory and immunological reactions [11]. The data of the present study showed that positive and significant correlations exist between BMI and pain severity, and age and radiographic features. BMI was reported as a predisposing factor for $\mathrm{OA}$ and its increased intensity is influenced by BMI [15]. The impact of age in increasing the clinical picture of $\mathrm{OA}$ as reflected by radiographic features has been reported through other studies [16].

\section{Conclusion}

Our study showed that $\mathrm{OA}$ is highly prevalent among the Libyan population, and the risk factors (age, obesity, injury, sedentary work) are well identified. This can help to address a useful prevention program of the modifiable risk factors.

\section{References}

1. Buckwalter JA, Lane NE (1997) Athletics and osteoarthritis. Am J Sports Med 25(6): 873-881.

2. Ziad M Hawamdeh, Jihad M Al Ajlouni (2013) The clinical pattern of knee osteoarthritis in Jordan: A hospital based study. Int J Med Sci 10(6): 790-795.

3. Gupta KB, Duryea J, Weissman BN (2004) Radiographic evaluation of osteoarthritis. Radiol Clin North Am 42(1): 11-41.

4. Woolf AD, Pfleger B (2003) Burden of major musculoskeletal conditions. Bull World Health Organ 81(9): 646-656.

5. S Glyn Jones, AJR Palmer, R Agricola, AJ Price, TL Vincent, et al. (2015) Osteoarthritis. Lancet 386(9991): 376-387.

6. Hiligsmann M, Cooper C, Arden N, Boers M, Branco JC, et al. (2013) Health economics in the field of osteoarthritis: An expert's consensus paper from the European Society for Clinical and Economic Aspects of Osteoporosis and Osteoarthritis (ESCEO). Semin Arthritis Rheum 43(3): 303-313.

7. Dieppe PA (1995) Clinical features and diagnostic problems in osteoarthritis. In: Klipple JH, Dippe PA, Practical Rheumatology. Mosby, London p. 141-156.

8. Oliveria SA, Felson DT, Reed JI, Cirillo PA, Walker AM (1995) Incidence of symptomatic hand, hip and knee osteoarthritis among patients in a health maintenance organization. Arthritis Rheum 38(8): 1134-1141.

9. Felson DT (2003) Epidemiology of osteoarthritis. In: Brandt KD, Doherty M, Lohmander S, Osteoarthritis ( $2^{\text {nd }}$ edn). OUP/Pharmacia p. 524. 
10. Jordan KM, Arden NK, Doherty M, Bannwarth B, Bijlsma JW, et al. (2003) EULAR recommendations 2003-an evidence based approach to the management of knee osteoarthritis: Report of a task force of the standing committee for International Clinical Studies Including Therapeutic Trials (ESCISIT). Ann Rheum Dis 62(12): 1145-1155.

11. Kim HA, Cho ML, Choi HY, Yoon CS, Jhun JY, et al. (2006) The catabolic pathway mediated by Toll-like receptors in human osteoarthritic chondrocytes. Arthritis Rheum 54(7): 2152-2163.

12. Liu Bryan R, Terkeltaub R (2010) Chondrocyte innate immune myeloid differentiation factor 88-dependent signaling drives procatabolic effects of the endogenous Toll-like receptor 2 /Toll-like receptor 4 ligands low molecular weight hyaluronan and high mobility group box chromosomal protein 1 in mice. Arthritis Rheum 62(7): 2004-2012.

13. Liu Bryan R, Pritzker K, Firestein GS, Terkeltaub R (2005) TLR2 signaling in chondrocytes drives calcium pyrophosphate dihydrate and

ISSN: 2574-1241

DOI: 10.26717/BJSTR.2018.11.002035

Kareem Al Rashdan. Biomed J Sci \& Tech Res

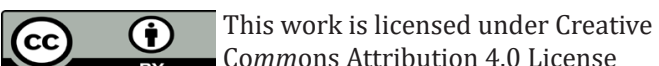

Submission Link: https://biomedres.us/submit-manuscript.php monosodium urate crystal-induced nitric oxide generation. J Immunol 174(8): 5016-5023.

14.Wang Q, Rozelle AL, Lepus CM, Scanzello CR, Song JJ, et al. (2011) Identification of a central role for complement in osteoarthritis. Nat Med 17(12): 1674-1679.

15. Hochberg MC, Armstrong LY, Yau M, Mitchell BD (2013) Genetic epidemiology of osteoarthritis: Recent developments and future directions. Curr Opin Rheumatol 25(2): 192-197

16. Reva C Lawrence, David T Felson, Charles G Helmick, Lesley M Arnold, Hyon Choi, et al. (2008) Estimates of the prevalence of arthritis and other rheumatic conditions in the United States, Part II. Arthritis Rheum 58(1): 26-35.

$\begin{array}{ll}\text { BIOMEDICAL } & \text { Assets of Publishing with us } \\ \text { RESEARCHES } & \text { - Global archiving of articles } \\ & \text { - Immediate, unrestricted online access } \\ \end{array}$

